\title{
THE FACTORS OF INFLUENCE ON THE FORMATION OF A REGIONAL TRANSPORT-LOGISTIC SYSTEM
}

\author{
Valentyna Aranchiy, Olexandr Pomaz, Julia Pomaz \\ Poltava State Agrarian Academy, Ukraine
}

\begin{abstract}
The kind and degree of the main external and internal factors' influence on the formation of regional transport-logistic system in Ukraine have been specified in the given article using determination method of environment profile.
\end{abstract}

Keywords: transport-logistic system, factors, region, transport-logistic management

DOI: $10.17512 /$ znpcz.2016.1.01

\section{Problem statement}

The end of the XXth - the turn of the XXIst centuries is characterized by logistization of supply, production, and trade activities of enterprises in developed countries. Transport is extremely important in logistics system because the circulation of material flows is impossible without it. Transport-logistic system is a complex system with the feedback; it performs various logistic functions and operations, consists of several subsystems, and has rather developed connections with external environment. The series of studies and experience of developed countries prove that the most effective way of developing the transport sector of Ukraine can be realized by the formation of transport-logistic system in the country on the whole and its separate regions. Thus, determining the factors of influence on the formation of the regional transport-logistic system in Ukraine is very important.

The works by Ukrainian and foreign scholars, such as: J.D. Bauersoks. D.D. Kloss, S.M. Minakova, O.D. Moroz, A.L. Nosov, V.I. Perebyynis, O.V. Perebyynis, O.V. Skoryk, V.I. Sergeyev, A.A. Kyzym, P.A. El'yashevych, O.V. Tkach, I.A. Voloshchuk, and others are devoted to the question of functioning and problems of transport-logistic system formation. The necessity of its development is put forward in these works. The scientists consider different aspects of developing and functioning of transport-logistics systems, theoretical and methodological backgrounds, and definitions in their works. A number of scholars recognize that insufficient replacement of fixed assets, the discrepancy of their technical level with modern requirements, slow updating of transport technologies and their not close connection with production, trade, storage, and customs technologies, low level of information system development of transport process are only a few factors that have a negative impact on the development of transport branch. So, the problem of determining the factors of influence on the regional transport-logistic system requires further research. 


\section{The statement of the purpose}

The purpose of this article is the revealing of the internal and external factors and macro-factors of the regional logistic-transport system formation in Ukraine, as well as defining the degree of their influence.

\section{The main materials of the investigation}

Freight logistics systems are commonly thought to be an indispensable component of modern societies. Accordingly, they are not only necessary in today's world, but can also provide many non-essential benefits to citizens. The operation of transportation determines the efficiency of moving products. The progress in techniques and management principles improves the movement of load, delivery speed, service quality, operation costs, usage of facilities, and energy saving. Reviewing the current conditions, a strong system needs a clear frame of logistics and a proper transport implements and techniques to link the production procedures. Logistics is defined as "the part of supply chain management that plans, implements, and controls the effectiveness of the flow of goods, their storage. It also concerns the services and corresponding information from the place of dispatch to the place of consumption in order to meet consumers' demands. Transportation is represented in this case by the word "flow". Transport provides the flow of materials in the supply chain from the places of dispatch to the places of destination, where the goods are consumed. Most businesses manage both incoming and outgoing logistics. Incoming logistics includes buying of materials and goods from suppliers. Outgoing logistics comprises the supply of materials and goods to customers. Therefore, transportation concerns both the incoming and outgoing sides of the business (Goldsby, Iyengar, Rao 2014).

V.I. Perebyynis and O.V. Perebyynis determine the transport-logistic management as a set of control functions and methods that are aimed at the rational use of transport resources in the process of transport-logistic provision of production-commercial activities of economic subjects and receiving profit (Перебийніс, Перебийніс 2006, p. 207).

According to the international experience, the most effective growth direction of Ukrainian transport sector can be implemented by the formation of transportlogistic system of the country which provides the cooperation of all the participants in transport-distribution process in organisational-economical, technical, technological, and informational aspects during the movement of cargo traffic flows and also enables to occupy the competitive positions on international markets of transport-logistic services (Мінакова 2014, pp. 844-847; Brzozowska 2015, pp. 182-188).

Transport-logistic system is a whole complex of the subjects of transportlogistic activities and objects of transport-logistic infrastructure that interact with each other for the purposes of optimizing the flow of cargo traffic from "the doorto-the door" at minimum cost and on most beneficial terms (Ткач, Волощук., 2013, pp. 221-226). 
Regional logistic systems are complex open economic systems which include sub-systems interacting with each other and with external environment. These subsysyems ensure the process of functioning economic relations of the regional branches and enterprises in the regional logistics chains, the formation of which is aimed at achieving social-economic goals of devepolment in the region on the basis of economic flows' optimization (Мороз 2010, p. 7).

For defining the system of factors for the regional transport- logistic system formation, for dividing them into external and internal, and for determining their significance, the fundamental principles of the Delphi method of expert assessment (Грабовецький 2003, pp. 120-158) as well as the determination method of the environment profile (Урожай Знань 2004) have been used. The experts' questionnaire survey has been conducted in two rounds. Expert group included 30 experts among whom there were professionals of agrarian and processing companies, teachers of higher educational establishments. In the first round of the survey, using the questionnaire the expertss defined the system of factors of the regional transport-logistic system formation, dividing them into external, internal factors, and macro-factors. In the second round, the experts worked with the questionnaire in which they could give their expert evaluation for every investigated factor. The expert evaluation was made according to the following grading scale:

- the importance of the factor for the regional transport-logistic system formation (3 - strong; 2 - moderate; 1 - weak);

- the impact on the formation of the regional transport-logistic system (3 - strong; 2 - moderate; 1 - weak; 0 - the impact is absent);

- the type of influence (+1 - positive; -1 - negative).

The result of the three above-mentioned expert estimations is integrated index that shows the degree of its importance for the enterprise (Урожай Знань 2004). The level of the experts' competence which was defined according to the method of S. D. Beshelyev and F. H. Hurevych was taken into account (Бешелев, Гуревич 1981, p. 214; Бауэрсокс 2001, p. 639).

The experts' evaluation results of external factors of the regional transportlogistic system formation have been represented in Table 1.

Transport-logistic system like every material system exists in the concrete environment that comprises everything which is outside the system. Each system constantly receives the materials, energy, information from the environment with the aim of ensuring its activities, growth, development, and improvement (Глобальные логистические системы 2001, p. 240; Носов 2007; Скорик 2014 pp. 200-206). The material system cannot be indifferent to the environmental influence. The system can develop successfully if the environment is favourable, but under the influence of negative factors the system may be destroyed.

It has been established that the key factors of the environment that have the impact on the formation of the regional transport-logistic system are:

- spatial balance between the production, processing and products' consumption regions ( 6 points, positive influence direction);

- reliability of transport means (6,6 points, the influence can be both positive and negative); 
- the level of prices on raw materials and power sources in the world and in the country ( 7,15 points, expressed negative influence);

- the possibility of increasing the number of automobiles by purchasing new machinery at the expense of commercial loans, financial leasing, government allowance ( 4,8 points, positive influence direction).

Table 1. The experts' analysis of external factors of the regional transportlogistic system formation

\begin{tabular}{|c|c|c|c|c|}
\hline The factors of external environment & $\begin{array}{l}\text { The } \\
\text { importance for } \\
\text { the formation } \\
\text { of transport- } \\
\text { logistic system }\end{array}$ & $\begin{array}{l}\text { The influence } \\
\text { on the } \\
\text { formation of } \\
\text { the regional } \\
\text { transport- } \\
\text { logistic system }\end{array}$ & $\begin{array}{l}\text { The } \\
\text { direction } \\
\text { of } \\
\text { influence }\end{array}$ & $\begin{array}{l}\text { The degree } \\
\text { of influence }\end{array}$ \\
\hline $\begin{array}{l}\text { 1. Spatial balance between production, } \\
\text { processing, and products' consumption } \\
\text { regions }\end{array}$ & 2,5 & 2,4 & +1 & 6 \\
\hline $\begin{array}{l}\text { 2. Available density and quality of traffic } \\
\text { network on the main routes outside the } \\
\text { enterprise }\end{array}$ & 1,95 & 1,96 & $+1 /-1$ & $3,8 /-3,8$ \\
\hline $\begin{array}{l}\text { 3. Reliability (permanent character of } \\
\text { transport means' specifications during } \\
\text { their operation) }\end{array}$ & 2,4 & 2,75 & $+1 /-1$ & $6,6 /-6,6$ \\
\hline $\begin{array}{l}\text { 4. The compliance of transport means' } \\
\text { design with working conditions and } \\
\text { load classification, their loading } \\
\text { capacity }\end{array}$ & 1,85 & 2,05 & $+1 /-1$ & $3,79 /-3,79$ \\
\hline $\begin{array}{l}\text { 5. The supply of loading-and-unloading } \\
\text { facilities on the market }\end{array}$ & 1,25 & 1,34 & +1 & 1,68 \\
\hline $\begin{array}{l}\text { 6. Organizational level of transport } \\
\text { processes outside the enterprise (traffic } \\
\text { capacity of roads that determines } \\
\text { transport road speed, working activities } \\
\text { of management concerning receiving, } \\
\text { weighing, loading and unloading } \\
\text { operations at processing companies) }\end{array}$ & 1.3 & 1.82 & $+1 /-1$ & $2,4 /-2,4$ \\
\hline $\begin{array}{l}\text { 7. Price level on raw materials and power } \\
\text { supply in the world and in the country }\end{array}$ & 2,6 & 2,75 & -1 & $-7,15$ \\
\hline $\begin{array}{l}\text { 8. Design peculiaritieses of transport } \\
\text { means, availability of spare parts' } \\
\text { supplies }\end{array}$ & 1,7 & 1,85 & $+1 /-1$ & $3,1 /-3,1$ \\
\hline $\begin{array}{l}\text { 9. Increasing the number of automobiles } \\
\text { by purchasing new machinery at the } \\
\text { expense of commercial loans, financial } \\
\text { leasing, government allowance (through } \\
\text { the partial compensation of the } \\
\text { purchased technology cost) }\end{array}$ & 2,0 & 2,4 & +1 & 4,8 \\
\hline 10. Staff training opportunities & 1,22 & 1,56 & +1 & 1,9 \\
\hline $\begin{array}{l}\text { 11. Developing of transport-logistics } \\
\text { infrastructure in the region }\end{array}$ & 1,1 & 1,4 & $+1 /-1$ & $1,54 /-1,54$ \\
\hline
\end{tabular}

Source: the results of experts 'questionnaire survey, own estimations. 
The more moderate influence is caused by such factors as availability, branching, density, and quality of traffic network on the main routes outside the enterprise ( 3,8 points, diversified influence); transport means' design compliance with working conditions and load classification, their loading capacity (3,79 points, diversified influence), and others (Figure 1).

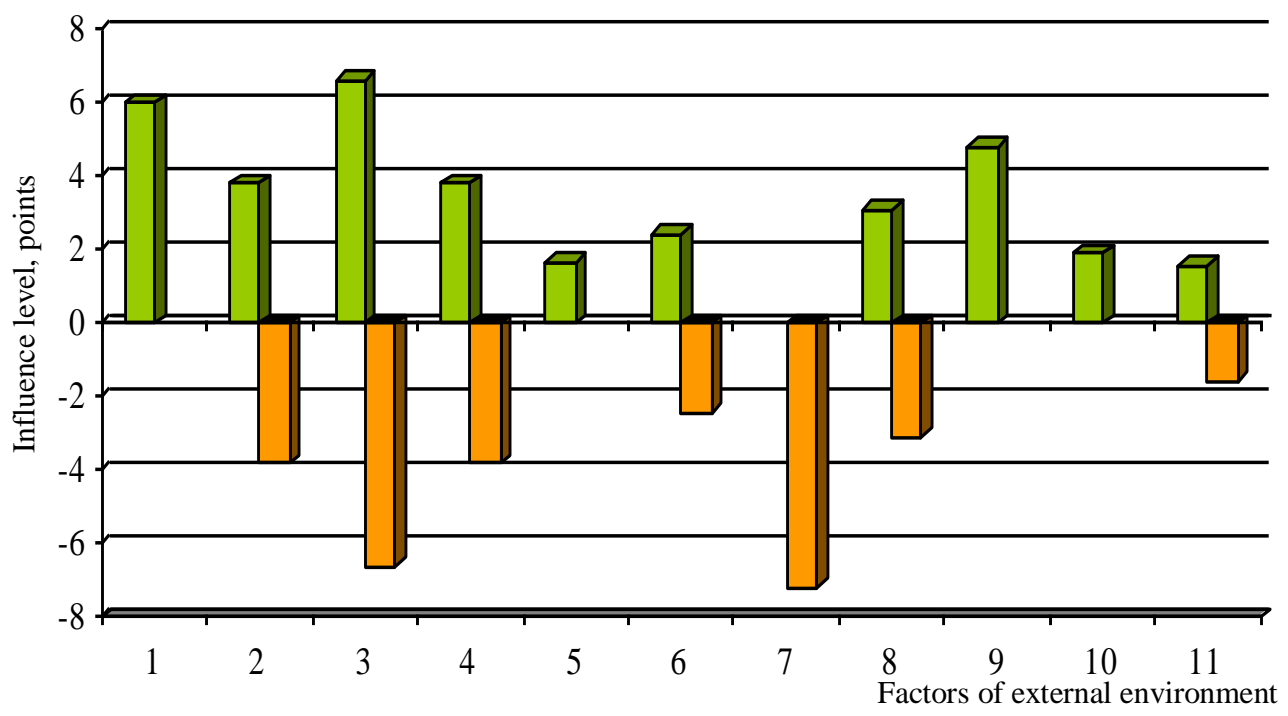

Figure 1. The level of external factor's influence on the formation of the regional transport-logistic system

Source: the results of experts' questionnaire survey, own estimations.

The experts' evaluation results of internal factors of the regional transportlogistic system formation have been represented in Table 2.

These factors should be payed special attention as they are typically subject to inspection and their influence is the subject to correction by the company's chief executives.

Internal environment of transport-logistic systems is a relative term and it largely depends on the accepted system of control. The biggest increase is achieved by such internal factors as management of coordinated functioning of harvesting units, hauling stock and loading/unloading machinery in the enterprise's premises ( 7,2 points, positive influence direction) and the management of the rational use of resources and energy at the enterprise (7,28 points, positive influence direction).

Such factors as timely high quality repairs of machinery and its maintenance at the enterprise, the use of components and assemblies of exchange stock $(6,65$ points, diversified influence), service life of transport means at the enterprise $(5,5$ points, negative influence direction), increasing the number of automobiles by purchasing new machines by the enterprises, reequipping the available means of transport according to the modern requirements $(5,64$ points, negative influence 
direction), timely grain transportation from harvesting units to the thrashing floor as it is required, the necessity of harvest transportation within the shortest possible period of time for ensuring its storage are also very important (5,87 points, diversified influence) (Figure 2).

Table 2. The experts' evaluation results of internal factors of the regional transport-logistic system formation

\begin{tabular}{|c|c|c|c|c|}
\hline Factors of internal environment & $\begin{array}{l}\text { The } \\
\text { importance for } \\
\text { the formation } \\
\text { of transport- } \\
\text { logistic system }\end{array}$ & $\begin{array}{l}\text { The influence } \\
\text { on the } \\
\text { formation of } \\
\text { thr regional } \\
\text { transport- } \\
\text { logistic system }\end{array}$ & $\begin{array}{l}\text { The } \\
\text { direction } \\
\text { of } \\
\text { influence }\end{array}$ & $\begin{array}{l}\text { The degree of } \\
\text { influence }\end{array}$ \\
\hline $\begin{array}{l}\text { 1. Spatial location of objects in the } \\
\text { enterprise's premises }\end{array}$ & 1,2 & 1,3 & $+1 ;-1$ & 1,$56 ;-1,56$ \\
\hline $\begin{array}{l}\text { 2. Availability, branching, density, and } \\
\text { quality of road network within the } \\
\text { enterprise }\end{array}$ & 1,8 & 1,9 & $+1 ;-1$ & 3,$42 ;-3,42$ \\
\hline $\begin{array}{l}\text { 3. Service life of transport means at the } \\
\text { enterprise }\end{array}$ & 2,2 & 2,5 & -1 & $-5,5$ \\
\hline $\begin{array}{l}\text { 4he assortment of optimal } \\
\text { composition of machinery concerning } \\
\text { loading capacity, type of work, and } \\
\text { classification rating at the enterprise }\end{array}$ & 1,9 & 2,2 & $+1 ;-1$ & 4,$18 ;-4,18$ \\
\hline $\begin{array}{l}\text { 5. The structure of machinery concerning } \\
\text { unloading, mechanical handling } \\
\text { facilities, the availability of loading- } \\
\text { and-unloading facilities, and weighing } \\
\text { devices at the enterprise. }\end{array}$ & 1,5 & 1,8 & $+1 ;-1$ & 2,$7 ;-2,7$ \\
\hline $\begin{array}{l}\text { 6. Management of coordinated } \\
\text { functioning of harvesting units, } \\
\text { loading/unloading machinery in the } \\
\text { enterprise's premises }\end{array}$ & 2,25 & 3,2 & +1 & 7,2 \\
\hline $\begin{array}{l}\text { 7. Management of the rational use of } \\
\text { resources and energy at the enterprise }\end{array}$ & 2,6 & 2,8 & +1 & 7,28 \\
\hline $\begin{array}{l}\text { 8. Timely and high quality repairs of } \\
\text { transport means and their maintenance } \\
\text { at the enterprise using the assemblies } \\
\text { of the renewed machine stock }\end{array}$ & 2,42 & 2,75 & $+1 ;-1$ & 6,$65 ;-6,65$ \\
\hline $\begin{array}{l}\text { 9. Increasing the number of automobiles } \\
\text { by purchasing new machines by } \\
\text { enterprises, renewing the available } \\
\text { means of transport according to } \\
\text { modern requirements }\end{array}$ & 2,3 & 2,45 & +1 & 5,64 \\
\hline $\begin{array}{l}\text { 10. The number of employees, involved } \\
\text { in transportation operations and } \\
\text { maintenance staff per one means } \\
\text { of transport, their qualification, } \\
\text { providing financial and moral } \\
\text { incentives for their activities, } \\
\text { consumer services }\end{array}$ & 2,25 & 2,3 & $+1 ;-1$ & 5,$18 ;-5,18$ \\
\hline $\begin{array}{l}\text { 11. The enterprise's reputation and image, } \\
\text { partnership relations }\end{array}$ & 2,3 & 2,55 & $+1 ;-1$ & 5,$87 ;-5,87$ \\
\hline
\end{tabular}

Source: results of experts questionnaire survey, own estimations. 


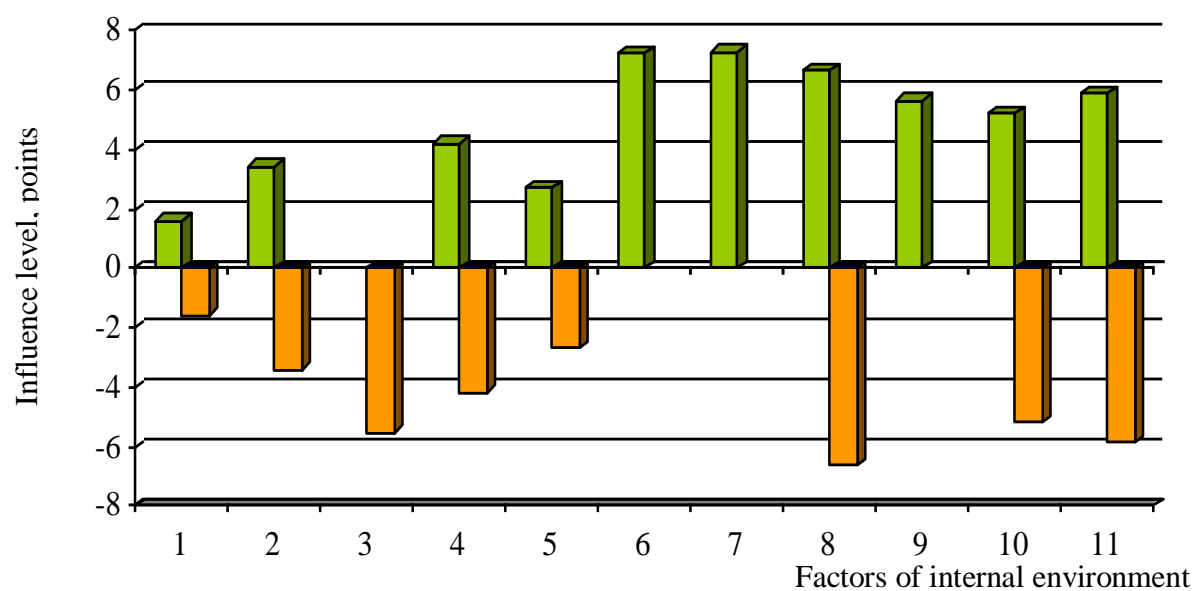

Figure. 2. The level of internal factors' influence on the formation of the regional transport-logistic system

Source: the results of experts' questionnaire survey, own estimations.

Besides the above mentioned factors, the so called macro-factors of external environment, in other words, external factors that have indirect impact and uncontrolled character are important for the formation of regional transport-logistic system (Table 3, Figure 3).

Table 3. The experts' evaluation results of macro-factors which have an impact on the formation of the regional transport-logistic system

\begin{tabular}{|c|c|c|c|c|}
\hline Macro-factors & $\begin{array}{l}\text { The } \\
\text { importance for } \\
\text { the formation } \\
\text { of transport- } \\
\text { logistic system } \\
\end{array}$ & $\begin{array}{l}\text { The influence on } \\
\text { the formation of } \\
\text { regional } \\
\text { transport-logistic } \\
\text { system } \\
\end{array}$ & $\begin{array}{l}\text { The } \\
\text { direction } \\
\text { of } \\
\text { influence }\end{array}$ & $\begin{array}{l}\text { The } \\
\text { degree of } \\
\text { influence }\end{array}$ \\
\hline 1. Critical state of the economy & 1,3 & 1,1 & -1 & $-1,3$ \\
\hline $\begin{array}{l}\text { 2. Military operations in the East of } \\
\text { Ukraine, terroristic threats, unstable } \\
\text { political situation, and confrontation of } \\
\text { political forces }\end{array}$ & 1,25 & 0,8 & -1 & -1 \\
\hline 3. The level of corruption in the country & 1,2 & 1,2 & -1 & $-1,44$ \\
\hline $\begin{array}{l}\text { 4. Substantial decrease in the value of the } \\
\text { national currency unit }\end{array}$ & 1,5 & 1.23 & -1 & $-1,85$ \\
\hline $\begin{array}{l}\text { 5. High level of inflation and } \\
\text { unemployment }\end{array}$ & 1,23 & 0,9 & -1 & $-1,1$ \\
\hline 6. Weather and climatic conditions & 1,1 & 0,8 & $+1 ;-1$ & $+0,88 ;-0,88$ \\
\hline $\begin{array}{l}\text { 7. Not al lthe passed laws have been } \\
\text { effective and obeyed }\end{array}$ & 1,2 & 1,2 & -1 & $-1,44$ \\
\hline $\begin{array}{l}\text { 8. The integration of the Ukrainian } \\
\text { transport system into the international } \\
\text { transport system }\end{array}$ & 1,9 & 1,5 & +1 & $+2,85$ \\
\hline
\end{tabular}

Source: the results of experts questionnaire survey, own estimations. 
The most important and the only positive macro-factor which influences the regional transport-logistic system formation is the prospective integration of the Ukrainian transport system into the international transport system that becomes possible as a result of joining World Trade Organisation and signing the Association Agreement between Ukraine and the European Union.

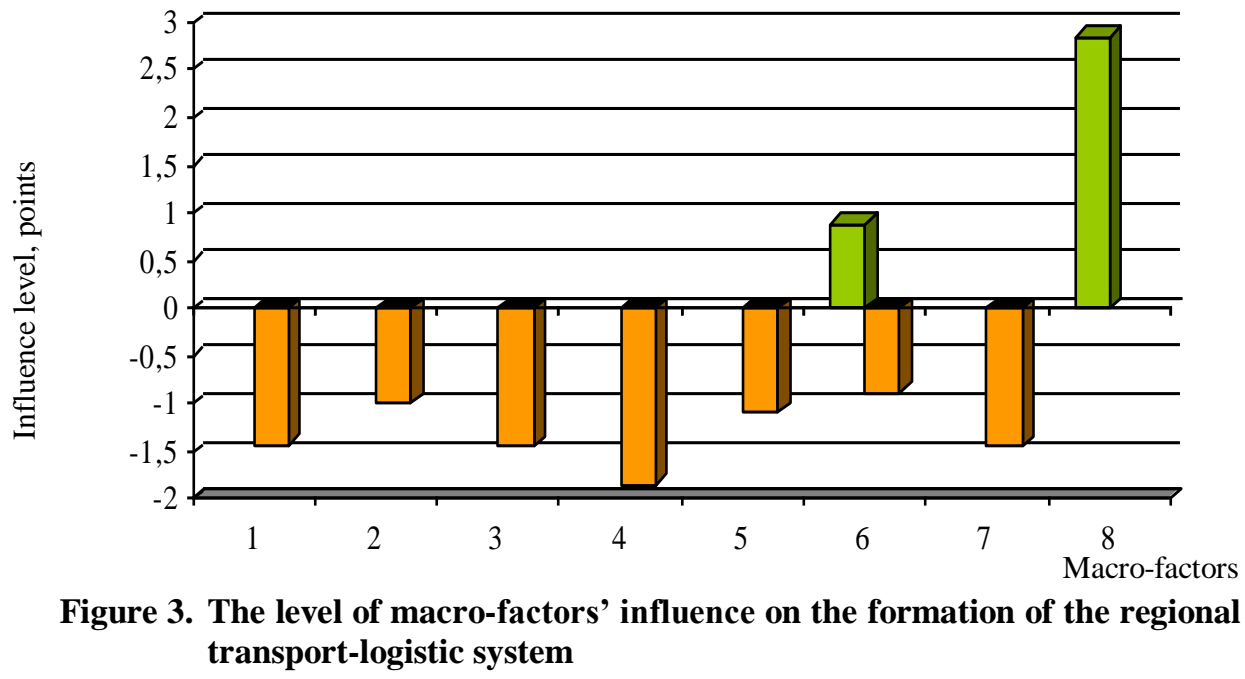

Source: the results of the experts' questionnaire survey, own estimations.

The Political part of the Agreement was signed on March 21, 2014, the Economic - on June27, 2014 (2,85 points).

The following factors have the negative influence:

- the deterioration of economic situation in our country (1,43 points, the negative influence direction);

- military operations in the East of Ukraine, terroristic threats which have extremely negative influence on political and legislative, social and economic situation in the country, bring the additional risks to Ukrainian enterprises, distract prospective investors (1 point, the negative influence direction);

- substantial devaluation of the national currency unit and as a consequence, increasing the prices of the means of production and raw materials, including vehicles, spare parts, lubricants, fuel, etc. (1,85 points, the negative influence direction);

- high level of corruption in the country $(1,44$ points, the negative influence direction);

- the imperfection of the legislative basis (not all the passed laws have been effective and obeyed (1,44 points, the negative influence direction).

- a high level of inflation and unemployment (1,1 points, the negative influence direction).

Such factor as weather-climatic conditions is variable $(0,88$ points, diversified influence). 


\section{Conclusions of the present observation}

According to given observation, the use of up-to-date methods is possible and necessary. New theoretical and practical approaches become more urgent in solving the problem of the regional transport-logistic system formation. One of such approaches is the method of defining environmental specifics. The undertaken study has permitted to reveal the main external, internal, and macro-factors of the regional transport-logistic system formation in Ukraine as well as define the degree of their influence.

\section{References}

1. Brzozowska A., Dacko M., Kalinichenko A., Sources and determinants of the innovativeness of enterprises. J. Actual problems of economics, $\mathrm{Nr} 9$ (171), 2015, pp. 182-188.

2. Goldsby T. J. , Iyengar D. , Rao S., The Critical Role of Transportation in Business and the Economy By CSCMP . Published Jan 16, 2014 by Pearson FT Press. Part of the Council of Supply Chain Management Professionals series. Access mode: http://www.ftpress.com/ authors/bio/f42e9e22-2bff-4d8f-9d72-ce16a792a2ef.

3. Бауэрсокс Дональд Дж. Логистика: интегрированная цепь поставок / Дж. Дональд Бауэрсокс, Дж. Дейвид Клосс; [пер. с англ.]. - М. : ЗАО «Олимп-бизнес», 2001, р. 639.

4. Бешелев С. Д., Гуревич Ф. Г., Экспертные оценки. - М.: Наука, 1981, р. 214.

5. Глобальные логистические системы: учеб. пособие/ [В. И. Сергеев, А. А. Кизим, П. А. Эльяшевич и др.]; под общ. ред. В. И. Сергеева. - СПб: Издательский дом «Бизнес-пресса», 2001, р. 240.

6. Грабовецький Б. С., Економічне прогнозування і планування: Навч. посіб. - К.: Центр навчальної літератури, 2003, pp. 120-158, p. 188.

7. Мінакова С. М. Обгрунтування конщептуальних засад розвитку логістичних транспортних систем в умовах глобалізаиії [Електронний ресурс] // Глобальні та національні проблеми економіки. - 2014. - груд. (Вип. 2), pp. 844-847. Режим доступу: http://global-national.in.ua/archive/2-2014/175.pdf.

8. Мороз О. Д., Формування регіональних логістичних систем: автореферат дисертації на здобуття наук. ступеня кандидата економічних наук; Луцький національний технічний університет. - Луцьк, 2010, p. 7, p. 17.

9. Носов А. Л. Региональная логистика / А. Л. Носов. - М. : Альфа-Пресс, 2007. - 168 с.

10. Перебийніс В. І., Перебийніс О. В., Транспортно - логістичні системи підприємств: формування та функиіонування: Монографія. - Полтава: РВЦ ПУСКУ, 2006, р. 207.

11. Скорик О. В. Особливості функціонування регіональних логістичних центрів і компаній України / О. В. Скорик // Регіональна економіка. - 2014. - №2(72), pp. 200-206.

12. Ткач О.В., Волощук I.А., Транспортно-логістичні системи: теоретичні основи формування та напрями розвитку // Наука й економіка. - 2013. - Вип. 3, pp. 221-226. Режим доступу: http://nbuv.gov.ua/j-pdf/Nie_2013_3_37.pdf.

13. Урожай Знань. Розвиток приватного бізнесу. Європейська Комісія та інші донори. Матеріали бізнес-тренінгів. Проведення діагностичного аналізу підприємства. Виконавець проекту Беарінг Поінт. - 2004.] Harvest of Knowledge. Private Business Development. European Commission and Other Donors. Business training materials. Enterprises Restructuring Facility Project. Bearing Point. - 2004. 
WPŁYW CZYNNIKÓW NA KSZTAŁTOWANIE SIĘ REGIONALNEGO SYSTEMU TRANSPORTOWO-LOGISTYCZNEGO

Streszczenie. W opracowaniu określono rodzaj i stopień wpływu głównych czynników zewnętrznych i wewnętrznych na kształtowanie się regionalnego systemu transportowologistycznego na Ukrainie z pomocą metody określania profilu środowiska.

Słowa kluczowe: system transportowo-logistyczny, czynniki, region, zarządzanie transportowo-logistyczne 